\title{
The hybrid methylene blue-zeolite system: a higher efficient photocatalyst for photoinactivation of pathogenic microorganisms
}

\author{
M. Smolinská · G. Č́́k · F. Šeršeň • M. Čaplovičová • \\ A. Takáčová • M. Kopáni
}

Received: 8 November 2012/Revised: 2 January 2013/Accepted: 2 November 2013/Published online: 5 December 2013

(C) Islamic Azad University (IAU) 2013

\begin{abstract}
The composite system can be prepared by incorporation of methylene blue (MB) into the channels of zeolite and by adsorption on the surface of the crystals. The composite photosensitizer effectively absorbs the red light $\left(\lambda_{\max }=648 \mathrm{~nm}\right)$ and upon illumination with light-emitting diode at a fluence rate of $1.02 \mathrm{~mW} \mathrm{~cm}{ }^{-2}$ generates effectively reactive singlet oxygen in aqueous solution, which was proved by EPR spectroscopy. To test efficiency for inactivation of pathogenic microorganisms, we measured photokilling of bacteria Escherichia coli and Staphylococcus aureus and yeasts Candida albicans. We found out that after the microorganisms have been adsorbed at the surface of such modified zeolite, the photogenerated singlet oxygen quickly penetrates their cell walls, bringing about
\end{abstract}

\author{
M. Smolinská \\ Department of Microbiology and Virology, Faculty of Natural \\ Sciences, Comenius University, Mlynská dolina B-2, \\ 84215 Bratislava 4, Slovakia \\ M. Smolinská $(\bowtie) \cdot$ G. Č́ík · A. Takáčová \\ Department of Environmental Engineering, Institute of Chemical \\ and Environmental Engineering, Faculty of Chemical and Food \\ Technology, Slovak University of Technology, Radlinského 9, \\ 81237 Bratislava, Slovakia \\ e-mail: miroslava.smolinska@yahoo.com \\ F. Šeršeň \\ Institute of Chemistry, Faculty of Natural Sciences, Comenius \\ University, Mlynská dolina, 84215 Bratislava, Slovakia

\section{M. Čaplovičová} \\ Department of Geology of Mineral Deposits, Faculty of Natural \\ Sciences, Comenius University, Mlynská dolina, \\ 84215 Bratislava, Slovakia \\ M. Kopáni \\ Institute of Pathological Anatomy, Faculty of Medicine, \\ Comenius University, Sasinkova 4, 81108 Bratislava, Slovakia
}

their effective photoinactivation. The growth inhibition reached almost $50 \%$ at 200 and $400 \mathrm{mg}$ modified zeolite in $1 \mathrm{ml}$ of medium in E. coli and C. albicans, respectively. On the other hand, the growth inhibition of $S$. aureus reached $50 \%$ at far smaller amount of photocatalyst (30 $\mu \mathrm{g}$ per $1 \mathrm{ml}$ of medium). These results demonstrate differences in sensitivities of bacteria and yeast growth. The comparison revealed that concentration required for $\mathrm{IC}_{50}$ was in case of $C$. albicans several orders of magnitude lower for a zeolite-immobilized dye than it was for a freely dissolved dye. In $S$. aureus, this concentration was even lower by four orders of magnitude. Thus, our work suggested a new possibility to exploitation of zeolite and MB in the protection of biologically contaminated environment, and in photodynamic therapy.

Keywords Disinfection - Light-emitting diode . Modified zeolite - Pathogens - Photodynamic effect . Singlet oxygen

\section{Introduction}

Photodynamic inactivation (PDI) of pathogenic microorganisms is based on the interaction of visible light and photosensitizer agent, which under photoactivation generates in situ short-lived cytotoxic species. Under excitation, the photosensitizer is converted from singlet to triplet state by an intersystem crossing. This process, in turn, interacts with surroundings molecules to yield radical species and hydrogen peroxide-known as the type 1 mechanism, or transfers its energy to molecular oxygen $\left({ }^{3} \mathrm{O}_{2}\right)$ to produce singlet oxygen $\left({ }^{1} \mathrm{O}_{2}\right)$ - known as the type 2 mechanism. Both types of PDI result in localized cell death; however, the principal photodynamic mechanism has been shown to 
be the type 2 mechanism, which generates the highly toxic ${ }^{1} \mathrm{O}_{2}$ (Weishaupt et al. 1976).

Over the last 20-30 years, there has been a great deal of interest in the roles played by ${ }^{1} \mathrm{O}_{2}$ in photoinduced processes in both plant and animal cells. Particular attention has been focused on photoinduced events that result in the cell death (Ledford and Niyogi 2005; Redmond and Kochevar 2006). The photoinitiated, ${ }^{1} \mathrm{O}_{2}$ mediated death of cells has been exploited in a number of ways, ranging from photodynamic cancer therapy (Dougherty et al. 1998) to an antimicrobial treatment (Hamblin and Hasan 2004; Mosinger et al. 2007).

A photosensitizing agent with potentially optimal properties for the treatment of microbial infections should be endowed with specific features in addition to the expected photophysical characteristics, such as a high quantum yield for the generation of both the long-lived triplet state and the cytotoxic ${ }^{1} \mathrm{O}_{2}$ species. Such features include the following (Jori et al. 2006):

- a large affinity toward microbial cells

- a broad spectrum of action in order to efficiently act on infections involving heterogeneous flora of pathogens

- a mechanism of cell inactivation minimizing the risk of inducing the selection of resistant strains or promoting the development of mutagenic processes

- and the possibility to identify a therapeutic window which allows (a) the extensive killing of the diseaseinducing microbial cells with minimal damage to the host tissue in the area of infection and (b) the prevention of the regrowth of the pathogens after the treatment

An important step in research of the PDI was the discovery that photosensitizers that are positively charged at physiological $\mathrm{pH}$ values, such as phenothiazines (Wilson et al. 1995), phthalocyanines (Minnock et al. 1996; Roncucci et al. 2004, 2011), and porphyrins (Merchat et al. 1996; Gelfuso et al. 2011; Gois et al. 2010), directly promote the photoinactivation of both Gram-positive and Gram-negative bacteria. While phenothiazine derivatives, such as methylene blue (MB), are naturally cationic owing to the involvement of one amino group in the $\pi$ electron cloud resonance, porphyrins and phthalocyanines can be transformed into cationic entities through the insertion of positively charged substituents into the peripheral positions of the tetrapyrrole and tetraazaisoindole macrocycle, respectively.

MB as a cationic organic dye exhibits significant antimicrobial properties (Wainwright and Crossley 2002; Tardivo et al. 2005; Saif Ur Rehman and Han 2013). It inhibits the growth of various organisms such as bacteria (Wainwright 1996; Wainwright et al. 1996), yeasts (Peloi et al. 2008), parasites (Schirmer et al. 2003), and viruses
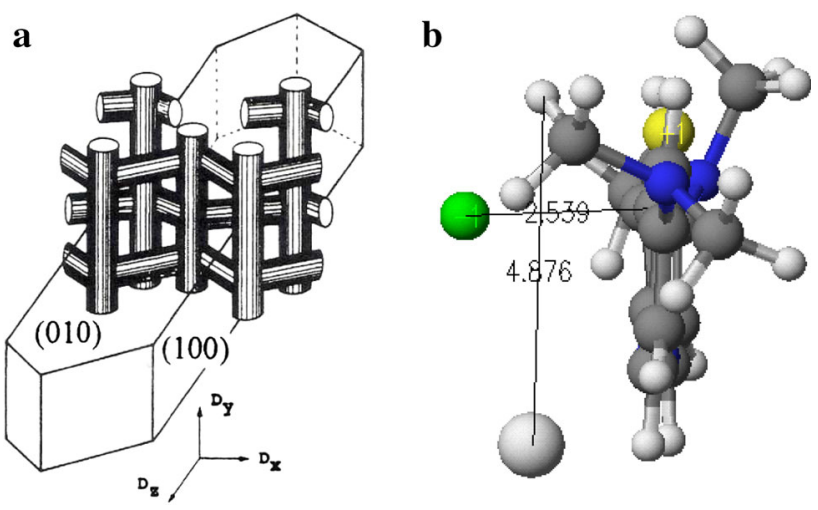

Fig. 1 Crystal structure of ZSM-5 zeolite (a); three-dimensional model of MB molecule-left-side view (b)

(Lee et al. 1997). Its antimicrobial efficiency is enhanced upon illumination with visible light, which indicates involvement of photosensitization mechanism in the MB activity. Under aerobic conditions, MB produces significant yields of ${ }^{1} \mathrm{O}_{2}$ and other reactive oxygen species that allow application of this dye as a disinfection agent with a nonspecific antimicrobial attack. The photochemical effects of MB blue depend on its molecular state. The antimicrobial efficiencies of MB are significantly reduced upon the formation of sandwich-type molecular dimers, socalled $H$-dimers, or larger assemblies. The $H$-type assemblies are not only less-effective generators of ${ }^{1} \mathrm{O}_{2}$, but also quench coexistent photoactive species (Gabrielli et al. 2004). Thus, aggregation causes very fast regress of ${ }^{1} \mathrm{O}_{2}$, because the absorbed energy is released mainly by nonradiative processes. By the use of a supporting structure, it is possible to control aggregation process and selfquenching of the dye, thus increasing its photostability (Lang et al. 2005; Lacombe et al. 2009). Immobilization of the dye creates a system, in which the photosensitizer and microorganisms stay in separate phases. In such a system, the degree of microorganisms deactivation depends largely on the concentration of the dye at the carrier and on the time of irradiation (Krouit et al. 2006).

During last three decades, considerable attention has been given to investigation of the catalytic properties of highly siliceous synthetic zeolite molecular sieves and to the reaction mechanisms imposed by such structures. In particular, the pentasil family of zeolites, of which ZSM-5 is an outstanding member, has exhibited very valuable catalytic properties, including high chemical selectivity, low coking (aging) tendency, and high turnover activity for a variety of chemical reactions. The dimensions of the pores in zeolite molecular sieves depend on the number of $\mathrm{Si}$ or $\mathrm{Al}$ tetrahedra in the rings that make up the pore. X-ray diffraction analyses show that ZSM-5 possesses two types of pores, both of which are composed of 10-membered 
tetrahedral rings, whereby one pore system is sinusoidal with a nearly circular cross section of about $0.55 \mathrm{~nm}$, the other pore system is straight and perpendicular to the sinusoidal system with elliptical pores of $0.52 \times 0.58 \mathrm{~nm}$ (Fig. 1; Caro et al. 1993).

Authors of the work (Meteš et al. 2004) investigated several synthetic zeolites for cleaning printing ink wastewater and found that adsorption is independent of the pore structure. They showed that ZSM-5 was effective, while other studied zeolites showed lower efficiency. Smaller crystals of zeolites will have larger surface areas and less diffusion limitations compared to zeolites with micrometer-sized crystals (Schmidt et al. 2000). Adsorption of the MB into unmodified ZSM-5 zeolite was studied by Jin et al. (2008). They found out that maximum of adsorbed MB-8.67 $\mathrm{mg} \mathrm{g}^{-1}$ into unmodified ZSM-5 zeolite can be achieved at $25{ }^{\circ} \mathrm{C}, p H=6.43$, depending on the internal surface area, ranging from 400 to $800 \mathrm{~m}^{2} \mathrm{~g}^{-1}$. This relatively high value is possible owing to the fact that cations in zeolite $\left(\mathrm{Na}^{+}\right)$may exchange with cations from solution and thus improve the adsorption capacity for cationic MB.

We now describe an attempt to convert an inert carrier (ZSM-5 zeolite) and active cationic sensitizer (MB) into a heterogeneous photoactive system, and study its visible light (red LED light) induced affects on pathogenic microorganisms (Gram-positive bacteria Staphylococcus aureus, Gram-negative bacteria Escherichia coli, and the yeasts Candida albicans). The experiments were realized in Department of Environmental Engineering and Department of Biochemistry and Microbiology, Faculty of Chemical and Food Technology, Slovak University of Technology in Bratislava, Slovakia (April-November 2010). The possible advantage of such a system may be the fact that zeolite ZSM-5 does not contain voluminous inner spaces; rather its inner structure is formed by a system of microchannels, suitable for holding molecules of sensitizer-MB. Thus, a stable system with tightly bound molecules of dye is created, useful for suppressing their possible aggregation such as was observed in the zeolite type $\mathrm{Y}$ with deposited thionine dye, the pores of which reach the diameter of $0.7 \mathrm{~nm}$ (Chrétien 2007). In the above-described system, it can be assumed that after the microorganisms have been adsorbed at the surface of such modified zeolite, the photogenerated ${ }^{1} \mathrm{O}_{2}$ quickly penetrates their cell walls, bringing about their effective photoinactivation.

\section{Materials and methods}

Preparation of composite ZSM-5-MB photocatalyst

The sodium form of ZSM-5 (Na-ZSM-5) was supplied by the VÚRUP, a.s., Slovakia (molar module $\mathrm{SiO}_{2} /$
$\mathrm{Al}_{2} \mathrm{O}_{3}=43.7$; BET surface area $=303.22 \mathrm{~m}^{2} \mathrm{~g}^{-1}$; volume of pores $=0.393 \mathrm{~cm}^{3} \mathrm{~g}^{-1}$; total absorption volume $=304.59 \times 10^{-6} \mathrm{~m}^{3} \mathrm{~g}^{-1} ; \quad$ Br $\phi$ nsted sites $=0.140$ mmol $\mathrm{g}^{-1}$ ). Zeolite was washed with distilled water to remove inorganic impurities, and $5 \mathrm{~g}$ of Na-ZSM-5 was lightly ground and immersed in $100 \mathrm{ml}$ of a deionized water ( $\mathrm{pH}$ 6.46) in which $0.4 \mathrm{~g} \mathrm{MB}$ (3,7-bis(dimethylamino)phenothiazin-5-ium chloride hydrate No. M9140; Sigma-Aldrich, USA) was added. The mixtures were shaken at $200 \mathrm{rpm}$ for $15 \mathrm{~h}$ at the laboratory temperature. Then, the modified zeolites were recovered by centrifuging and washing several times with distilled water to remove extra surfactants, dried in an oven at $120^{\circ} \mathrm{C}$, and then stored in a desiccator for later use.

\section{Characterization of the photocatalyst}

The diffuse reflectance of UV-VIS spectrum was recorded using an M-40 apparatus (Zeiss, Germany), and the transformation of data to Kubelka-Munk parameters was done. Pure ZSM-5 was used as a standard.

\section{Registration of photogenerated ${ }^{1} \mathrm{O}_{2}$ by EPR spectroscopy}

Formation of ${ }^{1} \mathrm{O}_{2}$ was determined using EPR method. Suspensions of $2 \mathrm{ml}$ of TEMP (2,2,6,6-tetramethylpiperidine) solution $\left(10^{-4} \mathrm{~mol}^{-1}\right)$ in chloroform with $20 \mathrm{mg}$ of modified zeolite were continually stirred in glass tubes and irradiated $\left(70 \mathrm{~W} \mathrm{~m}^{-2}\right)$ by a $250 \mathrm{~W}$ halogen lamp through $5 \mathrm{~cm}$ water filter for $5 \mathrm{~min}$. The generated ${ }^{1} \mathrm{O}_{2}$ was monitored indirectly by registration of an EPR signal from 2,2,6,6-tetramethylpiperidine- $N$-oxide (TEMPO) radical, which was formed by the reaction of TEMP with ${ }^{1} \mathrm{O}_{2}$. The first-derivative EPR spectra of TEMPO were recorded at modulation amplitude $0.1 \mathrm{mT}$ and microwave power $5 \mathrm{~mW}$ in ERS-230 apparatus (ZWG, Germany).

\section{Elemental analyses}

Elemental analyses of tested materials were carried out on a Vario Macro Cube (ELEMENTAR Analysensysteme $\mathrm{GmbH}$, Germany). Working temperature of the combustion tube was $1,150{ }^{\circ} \mathrm{C}$ and that of the reduction tube was $850{ }^{\circ} \mathrm{C}$. Helium $(99.996 \%)$ was used as the carrier gas $(120-125 \mathrm{kPa})$ at the flow rate of $600 \mathrm{ml} \mathrm{min}^{-1}$ and oxygen $(99.995 \%$; $200.0 \mathrm{kPa})$ as oxidizing agent. Sulfanilamide (ELEMENTAR Analysensysteme $\mathrm{GmbH}$ ) was used as the standard.

\section{Fluorescent, SEM, and TEM observation}

For fluorescence microscopy, an aliquot of microorganism suspensions after PDI was treated for 5 min with Hoechst 
33,342 dye $\left(10 \mu \mathrm{g} \mathrm{ml}^{-1}\right.$ in ethanol) and placed on the cover slip where it was analyzed under a Carl Zeiss Microimaging microscope (Gottingen, Germany), operating in epifluorescence mode using BP $330-380$ as the excitation filter, U-MWU as the emission filter, and BA 420 as a barrier filter. Images were made by a CCD camera. For scanning electron microscopy (SEM) investigations, $3 \%$ fixation solution of glutaraldehyde buffered by phosphate was used. Samples were dehydrated in graded acetone, subjected to critical point drying by $\mathrm{CO}_{2}$ (CPD 030, BALTEC, BG PRŐFZERT). Specimens were mounted on carbon stubs and coated with a layer of gold in ion-sputtering apparatus (SCD 050, BALZERS, Lichtenstein). Surface morphology of the zeolite samples was conducted by SEM with JXA 840A instrument (JEOL) with the accelerating voltage of $15 \mathrm{kV}$. The samples for transmission electron microscopy (TEM) analyses were fixed in glutaraldehyde solution (SERVA, Heidelberg, Germany) for $2 \mathrm{~h}$. After dehydrating the cells by graded alcohol, samples were embedded into Durcupan ACM (Fluka AG, Busch, Switzerland) and cut by ultramicrotome (C. Reichert, Wien, Austria) and contrasted with uranyl acetate-lead citrate. The thickness of samples was $100 \mathrm{~nm}$. The morphology of the microorganisms was studied by the analytical transmission microscope JEOL, model TEM 2000FX equipped with an ASID 20 band energy-dispersive probe Link AN 10,000. Transmission electrons were generated by electron gun with acceleration of $160 \mathrm{kV}$, resolution $0.28 \mathrm{~nm}$.

Photoinactivation of microorganisms with MB solution and ZSM-5-MB complex

The effect of MB on E. coli CCM 3988, Staphyloccocus aureus CCM 3953, and C. albicans CCM 8186 growth from the Czech Collection of Microorganisms (Masaryk University, Brno, Czech Republic) was determined by micro-dilution method, carried out in micro-plates type $\mathrm{P}$ (GAMA, Czech Republic). Mueller-Hinton broth (MHB) or Sabouraud glucose broth (SGB) was inoculated with overnight grown culture of microorganisms (final cells density was $10^{4} \mathrm{ml}^{-1}$ ). All experiments were carried out in two groups. One group was exposed to the light, and the other group was kept in the dark. Two control groups were prepared: one by adding $200 \mu \mathrm{l}$ broth with cells of microorganism (positive control) and the other by mixing $150 \mu \mathrm{l}$ of broth without microorganism with $50 \mu \mathrm{l}$ of MB solution (as a background). About $150 \mu \mathrm{l}$ broth inoculated by microorganism was added to $50 \mu \mathrm{l}$ of $\mathrm{MB}$ solution at final concentrations ranging from $1-35 \mu \mathrm{mol} 1^{-1}$ $\left(0.3739-13.0865 \mu \mathrm{g} \mathrm{ml}^{-1}\right), \quad 1-13 \mu \mathrm{mol} \mathrm{l^{-1 }} \quad(0.3739-$ $\left.4.8607 \mu \mathrm{g} \mathrm{ml}^{-1}\right)$, and $1-100 \mu \mathrm{mol} \mathrm{l}^{-1}(0.3739-37.3900$ $\mu \mathrm{g} \mathrm{ml}^{-1}$ ) for E. coli, S. aureus, and C. albicans, respectively (Peloi et al. 2008). The light source was placed vertically at the distance of $12 \mathrm{~cm}$ above the micro-plates. These micro-plates were irradiated under shaking at $37{ }^{\circ} \mathrm{C}$ for $8 \mathrm{~h}$ (E. coli and S. aureus) or $10 \mathrm{~h}$ (C. albicans). The bacteria or yeasts growth was quantified spectrophotometrically by ELx808 Absorbance Microplate Reader (BioTek, USA) at $630 \mathrm{~nm}$, measured until confluent growth. The antimicrobial effect of MB was read from toxicity curves.

The experiments in presence of ZSM-5-MB photocatalyst were carried out in 5-ml glass tubes (MHB or SGB with microorganism cells and particular amount of ZSM-5$\mathrm{MB})$. The amounts of photocatalyst were ranging from 100 to $400 \mathrm{mg} \mathrm{ml}^{-1}, 5 \times 10^{-3}$ to $0.2 \mu \mathrm{g} \mathrm{ml}^{-1}$, and 300 to $550 \mathrm{mg} \mathrm{ml}^{-1}$ for E. coli, S. aureus, and C. albicans, respectively. The control samples were cultivated without the presence of photocatalyst, and every sample in experiments was prepared in three parallels. The light sources were placed vertically at the distance of $12 \mathrm{~cm}$ above the glass tubes. These tubes were irradiated under shaking at $37^{\circ} \mathrm{C}$ and cultivated for $8 \mathrm{~h}$ (E. coli and S. aureus) or $10 \mathrm{~h}$ (C. albicans). The standard plate count method was used to determine the total number of viable cells as the colonyforming units (CFU; Houghtby et al. 1992). The initial sample was diluted through serial dilution in saline $10^{-1}$ $10^{-9}$ and $10^{-1}-10^{-7}$ for bacteria and yeasts, respectively. Diluted sample $(100 \mu \mathrm{l})$ was placed on a sterile Petri agar plate with the Mueller-Hinton agar (MHA) or Sabouraud glucose agar (SGA) in triplicate sets. After incubation $\left(24 \mathrm{~h}\right.$ at $30^{\circ} \mathrm{C}$ ), the number of colonies was counted (mean value of three experiments). Each experiment was followed by the experiment carried out in the dark. The number of viable cells as CFU was calculated as a percentage in comparison with the control without zeolite complex (100\% growth).

For the light experiments, the LEDs (ImportExport, a.s., Slovakia) system (constructed using 4 units with 19 individual LEDs) was used. Emission spectrum of light system and radiation flux density were measured with an optical fiber high resolution of Red Tide USB650 Fiber Optic Spectrometer (Ocean Optics, USA). Radiation flux density was $1.02 \mathrm{~mW} \mathrm{~cm}^{-2}$.

\section{Results and discussion}

In Fig. 2 is presented the differential reflectance spectrum of MB incorporated into the channels of zeolite ZSM-5 and adsorbed at the crystal surface (ZSM-5-MB). The shape of the spectra indicates both MB in channels and MB adsorbed at the surface effectively absorbed the light with $\lambda_{\max }=648 \mathrm{~nm}$. The inspection of spectrum also shows that below $600 \mathrm{~nm}$ there are no significant maxima indicating the formation of dimers or bigger MB clusters 


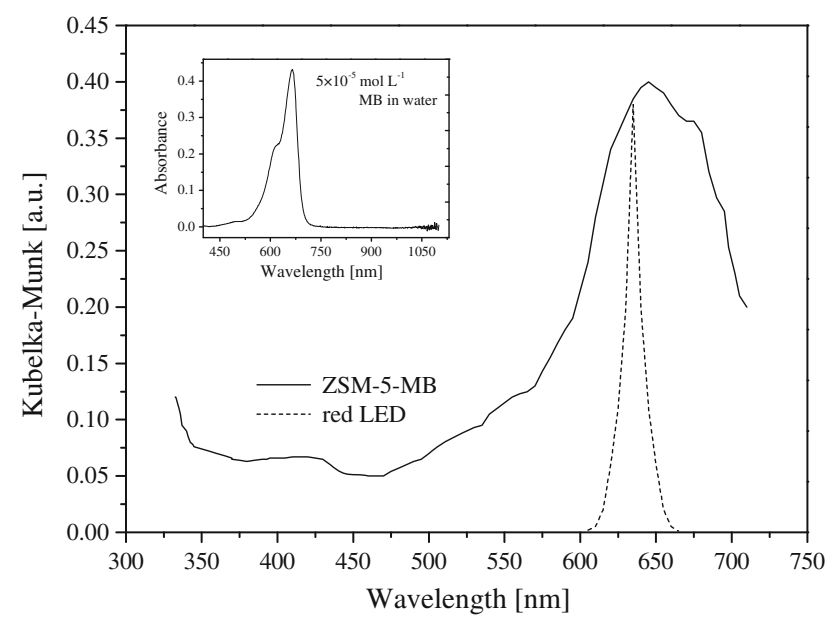

Fig. 2 Differential reflection UV-VIS spectrum of the ZSM-5-MB/ ZSM-5 and red LED emission spectrum

(Tardivo et al. 2005). Such dimmers were observed after incorporation of thionine into substantially larger cavities of zeolite type $\mathrm{Y}(\varnothing \sim 0.7 \mathrm{~nm})$ and supercages with $\varnothing=1.18 \mathrm{~nm}$ (Chrétien 2007). Calzaferri and Gfeller (1992) have reported that MB cannot be incorporated in the pore of zeolite $\mathrm{L}$, but adsorbed on the external surface to form aggregates. In the study of Arvand et al. (2003) was showed that MB molecules are intercalated in the channels of mordenite zeolite as monomeric and dimeric species. The ZSM-5-MB spectrum is in fact in good agreement with the spectrum of aqueous MB (inserted spectrum in Fig. 2; $c=5 \times 10^{-5} \mathrm{~mol} \mathrm{l}^{-1}$ ). This fact, in addition to the maximum of LED irradiation light lying close to the absorption maximum of heterogeneous sensitizer ZSM-5-MB, is both conducive to the effective photochemical generation of ${ }^{1} \mathrm{O}_{2}$.

Shirazi et al. (2008) studied the effect of conditions during synthesis of ZSM-5 zeolite on the morphology and size its crystals. According to their results, the molar ratio $\mathrm{Si} / \mathrm{Al}$ does affect the BET surface area. At molar ratio 40, the BET surface area reached $386 \mathrm{~m}^{2} \mathrm{~g}^{-1}$ at crystals size of approximately $7 \mu \mathrm{m}$. Compared to our zeolite (BET surface area $=303.22 \mathrm{~m}^{2} \mathrm{~g}^{-1}$ ), these values are somewhat higher. That is why the adsorption capacity of our zeolite was lower. The lower amount of physically adsorbed MB compared to published values (Jin et al. 2008) may have been the result of thorough washing of modified zeolite by deionized water, which could have broken down some of the dye aggregates. This indicates that MB is preferentially adsorbed at the outer surface of crystals.

The absence of higher MB aggregates at the zeolite surface was proven by comparing the TEM pictures of unmodified and modified zeolite (not shown). We are thus safe to assume that MB, present at both inner and outer surface of zeolite crystal, would, after being irradiated with

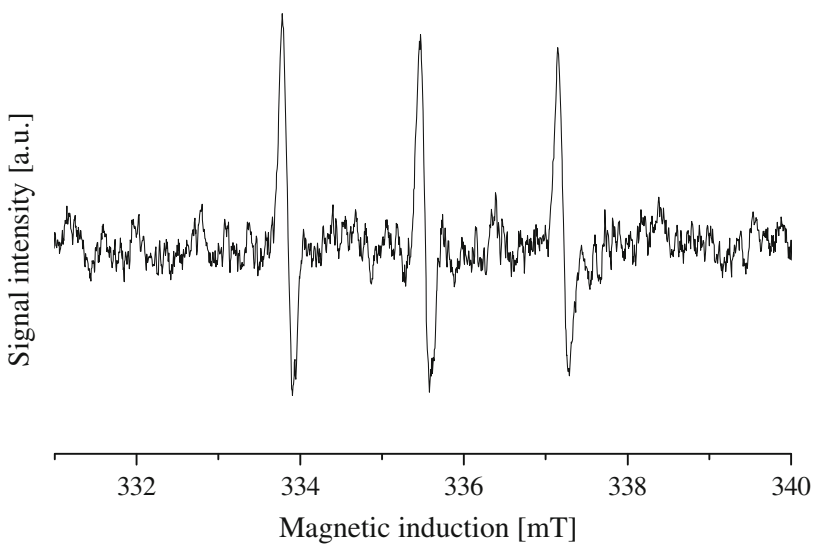

Fig. 3 EPR spectrum of the mixture of $20 \mathrm{mg}$ photocatalyst and $2 \mathrm{ml}$ of TEMP $\left(10^{-4} \mathrm{~mol} \mathrm{l}^{-1}\right)$ after 5 min irradiation $(\lambda>400 \mathrm{~nm})$

visible light $(\lambda>400 \mathrm{~nm})$, effectively excite molecules of sensitizer (MB), followed by generation of ${ }^{1} \mathrm{O}_{2}$ species. ${ }^{1} \mathrm{O}_{2}$ generated by irradiation of the suspension $\mathrm{H}_{2} \mathrm{O}-\mathrm{ZSM}-5$ MB by visible light in the presence of $10^{-4} \mathrm{~mol}^{-1}$ TEMP is illustrated in Fig. 3. In this figure, one can see triplet corresponding to EPR signal of TEMPO, generated after TEMP has been oxidized by ${ }^{1} \mathrm{O}_{2}$. The spectroscopic parameters of TEMPO in the studied suspension were as follows: $g=2.0034$; splitting constant $1.59 \mathrm{mT}$, in good agreement with the published data (Bujdák et al. 2009; Pavlíková et al. 2010; Šeršen et al. 2011). It can this be said that the heterogeneous system ZSM-5-MB effectively generates ${ }^{1} \mathrm{O}_{2}$, and therefore, we used the system to photoinactivation of pathogenic microorganisms.

First, it was necessary to test the behavior of the host material alone (crushed synthetic ZSM-5 zeolite without any photosensitizer) toward microorganisms. No microbial inactivation was noticed either in the presence of zeolite in darkness and light conditions as it is presented in previous studies of Čík et al. $(2001,2006)$ or by irradiation (red LED light) of the suspension without any added material. After this control analysis, we could start to test our modified zeolite on inactivation of various pathogens such as Gramnegative bacteria E. coli, Gram-positive bacteria S. aureus, and yeast $C$. albicans. In all experiments, the control samples were cultivated without the presence of ZSM-5MB system and every sample was prepared in three parallels. Experiments carried out in the presence of ZSM-5MB complex in dark conditions (Fig. 4) were also needed in our study where no growth inhibition was proved. Figures 4 and 5 demonstrate that the live cell counts of both bacteria and the yeast depend on the amount of the photocatalysts used and exposure time $(8 \mathrm{~h}$ for bacteria, $12 \mathrm{~h}$ for the yeasts). We could assume that this fact is associated with the increasing concentration of ${ }^{1} \mathrm{O}_{2}$ generated during irradiation as reported by the studies of Wainwright and Crossley (2002) and Benabbou et al. (2011). The most 

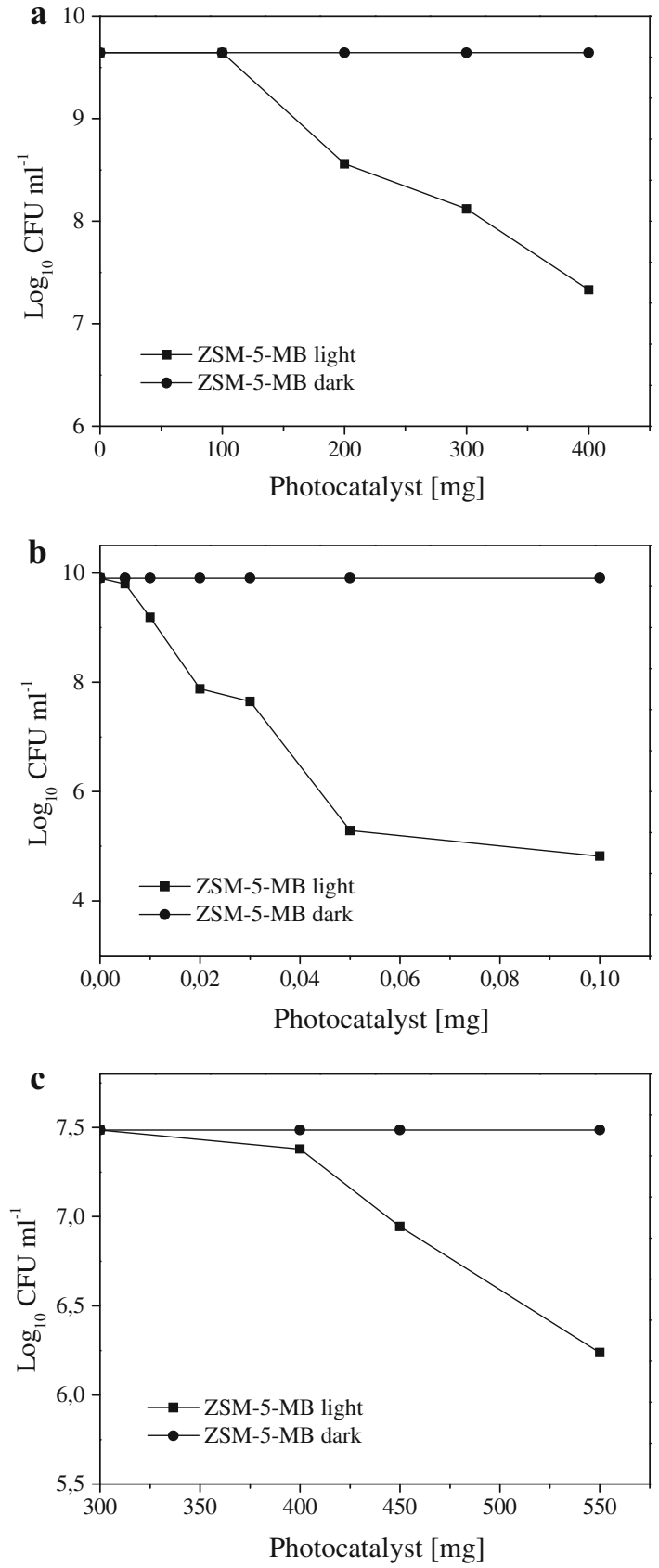

Fig. 4 Results of 648-nm light inactivation of a range of environmentally important bacteria $E$. coli (a) and $S$. aureus $(\mathbf{b})$ and yeasts $C$. albicans (c) at an irradiance of $1.02 \mathrm{~mW} \mathrm{~cm}-2$

sensitive to photodeactivation was the $S$. aureus, whereas C. albicans was the least sensitive species. These findings are in agreement with the results obtained from inhibition experiments carried out in a medium containing dissolved MB (Peloi et al. 2008). Difference in susceptibility of the microorganisms to the photocatalyst can be due to a different cell structure and its synthesis during the growth phase. Thus, we reached the specific inhibition growth of bacteria and yeast cells in the combination of light and
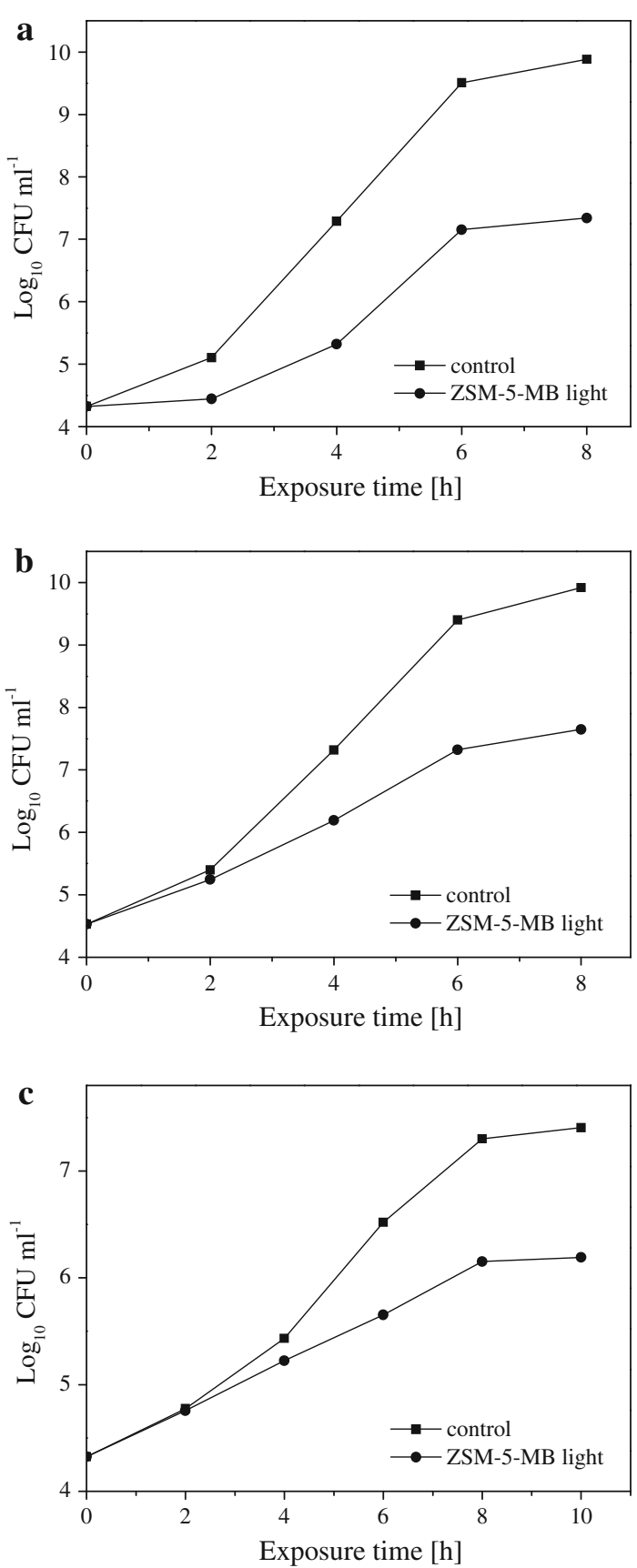

Fig. 5 The time dependence of cells counts on time irradiation with red LED light or growth curve of microorganisms: E. coli (a), $S$. aureus (b), and C. albicans (c)

ZSM-5-MB heterogeneous system, and therefore, we could assume that the MB present inside and on the surface of the zeolite crystals exhibits biological activity.

The best photodynamic response rate to eliminate bacteria was reached with an approximately $2.5-\log _{10}$ reduction in CFU counts (50\%) observed following exposure to 648-nm light with an irradiance of $1.02 \mathrm{~mW} \mathrm{~cm}^{-2}$ for E. coli at $200 \mathrm{mg}$ ZSM-5-MB in $1 \mathrm{ml}$ of medium. On the other hand, the growth inhibition of $S$. aureus reached 
Fig. 6 Images taken by fluorescence microscope: E. coli (a), S. aureus (c), and $C$. albicans (e) cultivated without red LED light in the presence of ZSM-5-MB; E. coli (b), S. aureus (d), and $C$. albicans (f) cultivated under red LED light in the presence of ZSM-5$\mathrm{MB}$; bacteria were cultivated for $8 \mathrm{~h}$ and yeasts for $12 \mathrm{~h}$
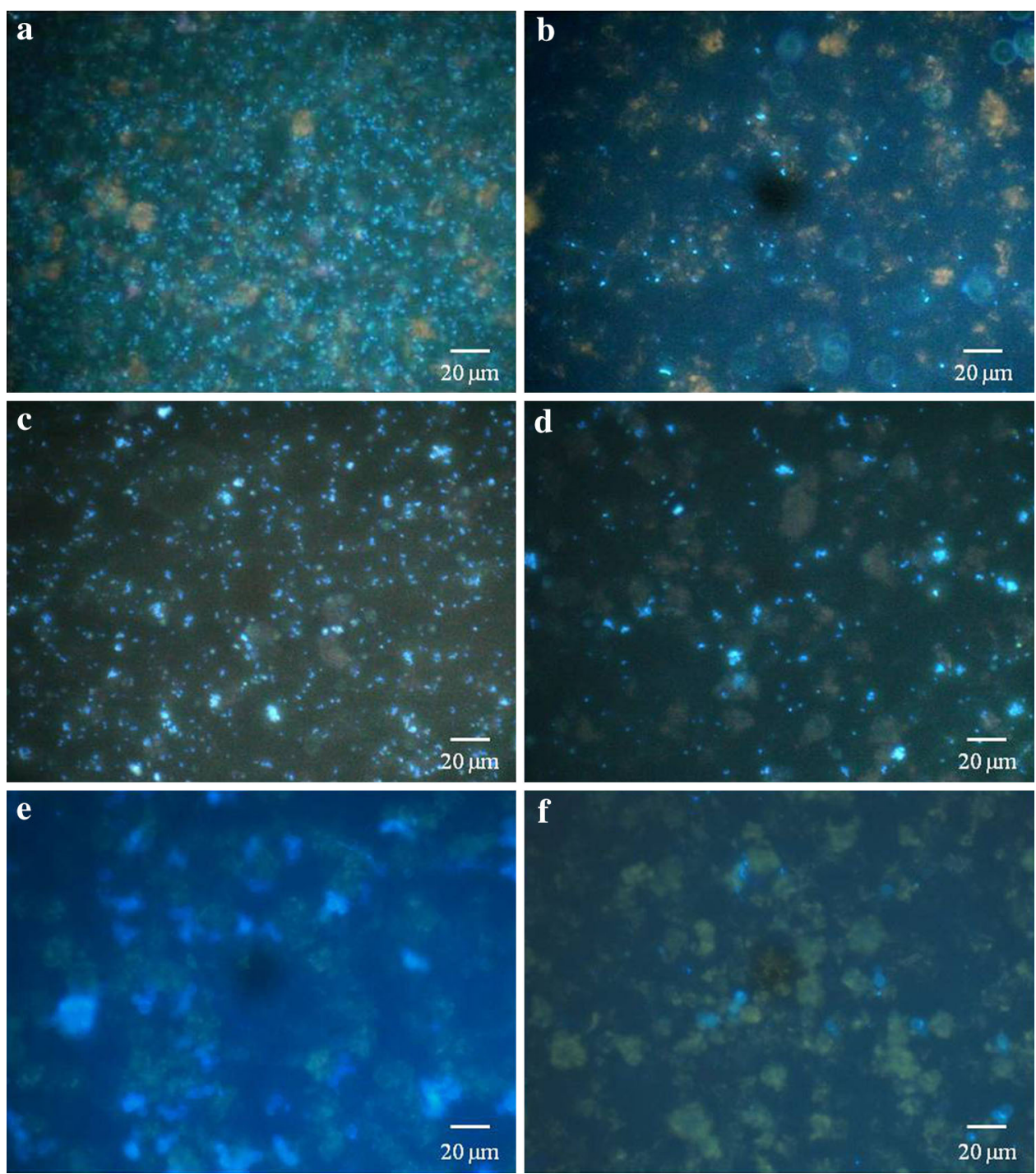

approximately $2.5-\log 10$ reduction in CFU counts $(50 \%)$ at far smaller amount of ZSM-5-MB (30 $\mu \mathrm{g}$ per $1 \mathrm{ml}$ of medium). The highest growth inhibition of $C$. albicans was reached at amount of $550 \mathrm{mg}$ modified zeolite per $1 \mathrm{ml}$ of medium namely approximately $1.5-\log _{10}$ reduction in CFU counts $(50 \%)$. The growth of $S$. aureus was influenced more than the cells growth of E. coli. The results confirm us that Gram-positive bacteria $S$. aureus are more susceptible to MB photoinactivation as compared to Gram-negative bacteria $E$. coli. This difference is generally attributed to variability in photosensitizers binding to the bacterial surface and also to structural differences in bacterial cell wall which limit penetration of active ${ }^{1} \mathrm{O}_{2}$ species (Ergaieg and Seux 2009). Gram-negative and Gram-positive bacteria possess profound differences in their three-dimensional architecture. Both groups of bacteria present an outer cell wall. In particular, in Gram-positive bacteria, the outer wall (15-80 nm thick) contains up to 100 peptidoglycan layers, which are intimately associated with lipoteichoic and negatively charged teichuronic acids. This wall displays a relatively high degree of porosity, since various macromolecules, such as glycopeptides and polysaccharides with a molecular weight in the 30,000-60,000 range, were found to readily diffuse to the inner plasma membrane. Thus, in this class of bacteria, the outer wall does not act as a nonpermeability barrier for the most commonly used photosensitizers. On the contrary, the outer wall of Gram-negative bacteria possesses an additional 10-15-nm-thick structural element, which is external to the peptidoglycan network and has a very heterogeneous composition. Such a highly organized system inhibits the penetration of host cellular and humoral defense factors and triggers mechanisms of resistance against foreign species. It is thus necessary to devise suitable strategies that enhance the permeability of the outer wall in order to make Gramnegative bacteria sensitive to the action of photodynamic 
processes (Jori et al. 2006). PDI can be also used to inactivate yeasts and fungi. Yeasts constitute a large group of rather disparate eukaryotic organisms, which are also enveloped by the presence of a thick external wall, composed of a mixture of glucan, mannan, chitin, and lipoproteins and separated from the plasma membrane by periplasmic space. The available evidences point out that response of such cells to photosensitized processes is less strictly controlled by structural factors as compared with Gram-negative bacteria (Paardekopper et al. 1995). The existence of protective mechanism against ${ }^{1} \mathrm{O}_{2}$ has been known. It is based on the presence of carotenoids, taking over the excitation from $\mathrm{MB}$, thus lowering the concentration of ${ }^{1} \mathrm{O}_{2}$. This contributes to the inhibition effect of ${ }^{1} \mathrm{O}_{2}$ on vital cells (Benabbou et al. 2011; Dahl et al. 1989). Higher resistance in C. albicans to killing by ${ }^{1} \mathrm{O}_{2}$ is the result of presence of nuclear membrane, acting as additional barrier against penetration of ${ }^{1} \mathrm{O}_{2}$ (Zeina et al. 2001), or caused by cell size, these cells being 25-50 times larger than are cells of $S$. aureus and E. coli (Zeina et al. 2001; Calzavara-Pinton et al. 2005). While smaller cells of tested bacteria are killed after being hit, and the effect spread over entire cell, at sensitive sites by single ${ }^{1} \mathrm{O}_{2}$, substantially larger yeasts require multiple hits.

In order to illuminate the inactivation mechanism of tested microorganisms and to evaluate the effectiveness of the ZSM-5-MB sensitizer, we compared the counts of surviving cells cultivated with and without the presence of red LED light. Figure 6 shows frames obtained in the fluorescence microscope of labeled bacteria and yeasts, incubated in the dark and after finished photoinactivation. These pictures show that the cells of all three tested microorganisms get into close contact with the ZSM-5-MB crystals already at "dark" cultivation. However, the cell count after light cultivation plummeted. The direct contact of tested cells in medium with the heterogeneous surface is also supported by pictures taken by the SEM technique (Fig. 7). As can be observed in Fig. 7, the microorganisms sticked and concentrated around ZSM-5-MB system. The contact between modified zeolite and bacteria or yeast surface could induce a stress to the microorganisms making them less resistant against external attacks. The lifetime of singlet oxygen, which is only 3-7 $\mu$ s in aqueous environment, makes it possible to cross only very short distances not exceeding $0.1 \mu \mathrm{m}$. Thus, the microorganisms must take time to diffuse toward silica particles, to closely link to the material in order to allow the generated ${ }^{1} \mathrm{O}_{2}$ to reach targets on microorganisms (Benabbou et al. 2011). Many studies of phenothiazine dyes on the various microorganisms illustrated that the adhesion of photosensitizers to microorganism cells is achieved via electrostatic interactions between the positive charged carried by the photosensitizer ions and the negatively charged groups on the outer surface
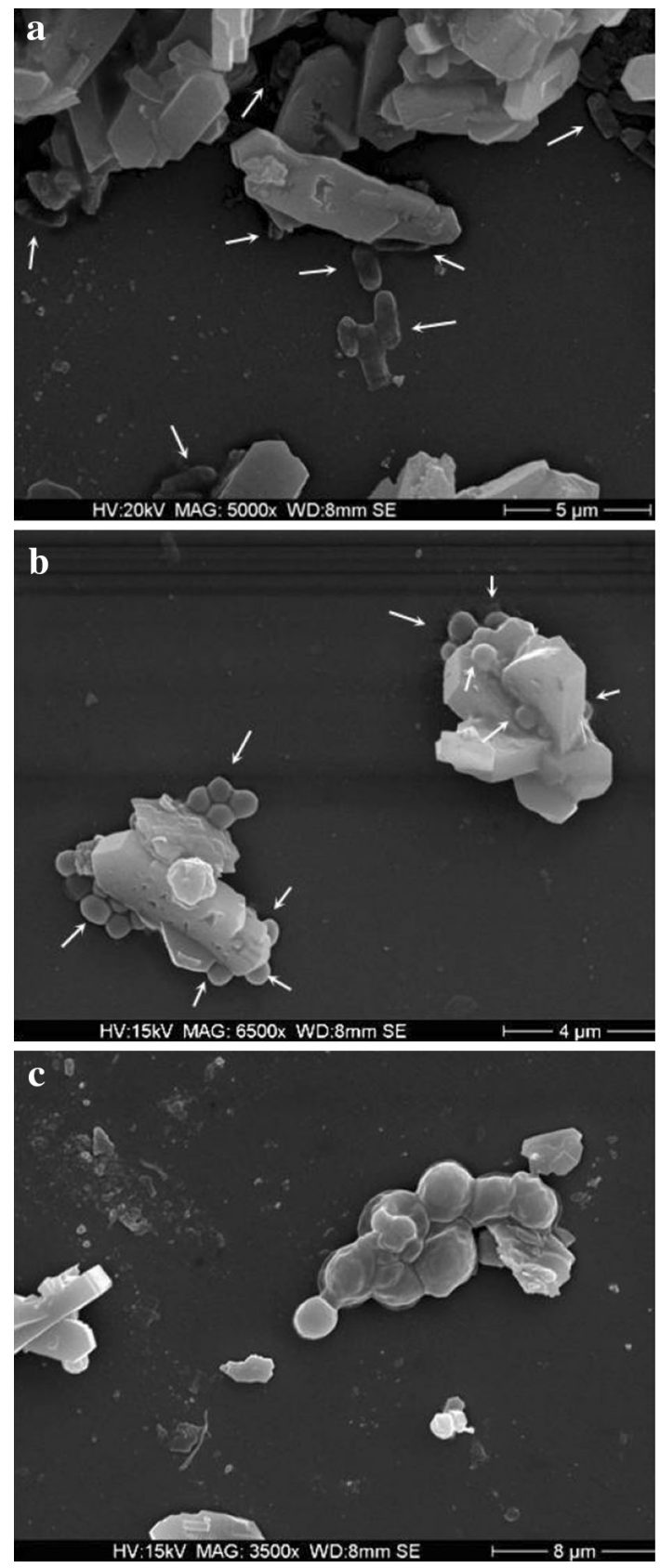

Fig. 7 Images generated by SEM: E. coli (a), S. aureus (b), and $C$. albicans (c) with the effect of red LED light. The pictures clearly show microorganisms being in contact with the crystals of zeolite photocatalyst

of the cell walls (Mellish et al. 2002; Phoenix and Harris 2003; Harris et al. 2005).

It can thus be assumed that the decisive factor in inactivation bacteria is the lifetime of ${ }^{1} \mathrm{O}_{2}$ species, within which it can penetrate the cell wall and destroy the cell by its cytostatic effect. In such a scenario, it is essential that heterogeneous sensitizer comes into "direct contact" with surface of microorganism during the illuminated cultivation, i.e., the phase in ${ }^{1} \mathrm{O}_{2}$ which is generated. The time 
Fig. 8 Microorganisms on TEM images after the photodynamic effect of photosensitizer ZSM-5-MB; E. coli (a), S. aureus (c), and $C$. albicans (e) cultivated in darkness; E. coli (b), S. aureus (d), and C. albicans (f) exposed during the cultivation to red LED light
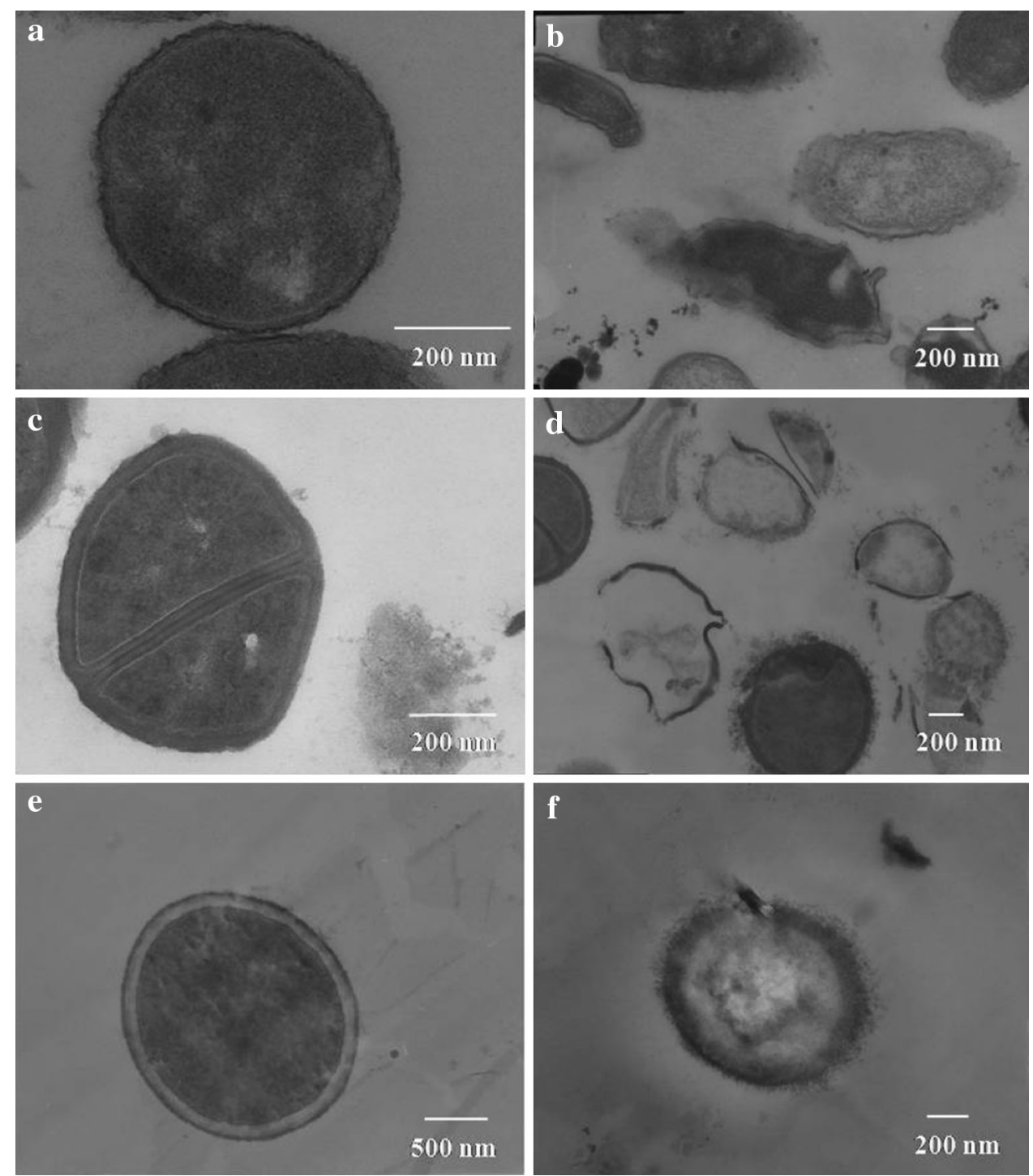

Table 1 Comparison of dissolved MB and MB immobilized on the zeolite ZSM-5, required for reaching the $\mathrm{IC}_{50}$ values of inactivated microorganisms

\begin{tabular}{lll}
\hline Microorganism & $\begin{array}{l}\text { MB dissolved in } \\
\text { medium }\left(\mathrm{mol} \mathrm{l}^{-1}\right)\end{array}$ & $\begin{array}{l}\text { MB immobilized on ZSM-5 } \\
\text { in medium }\left(\mathrm{mol} \mathrm{l}^{-1}\right)\end{array}$ \\
\hline E. coli & $1.03 \times 10^{-2}$ & $2.70 \times 10^{-3}$ \\
S. aureus & $2.44 \times 10^{-3}$ & $2.03 \times 10^{-7}$ \\
C. albicans & $1.57 \times 10^{-2}$ & $3.71 \times 10^{-3}$ \\
\hline
\end{tabular}

Concentrations of MB immobilized the zeolite ZSM-5 were calculated from elemental analysis data, using the amount of heterogeneous sensitizer required to reach $\mathrm{IC}_{50}$

dependence of ${ }^{1} \mathrm{O}_{2}$ generation was studied by Lissi and Rubio (1990). The authors found that in water ${ }^{1} \mathrm{O}_{2}$ reaches at lifetime $\tau_{1}=1 \mathrm{~ns}$ the mean molecular trajectory of $1.6 \mathrm{~nm}$, at $\tau_{2}=100 \mathrm{~ns}$ it was $16 \mathrm{~nm}$, and at $\tau_{3}=4 \mu \mathrm{s}$ $100 \mathrm{~nm}$. Measurements of ${ }^{1} \mathrm{O}_{2}$ in zeolite of the type $\mathrm{Y}$ revealed (Jockusch et al. 2005) that the ${ }^{1} \mathrm{O}_{2}$ depended on the environment (incorporated sensitizer) in the channels of zeolite. In case of thionine, structurally similar to $\mathrm{MB}$, the lifetime of ${ }^{1} \mathrm{O}_{2}$ reached $2.8 \pm 0.1 \mu$ s. Pace and Clennan (2002) determined $7.5 \mu$ s as upper limit of ${ }^{1} \mathrm{O}_{2}$ lifetime, when generated in $\mathrm{Y}$ zeolite type with incorporated $\mathrm{MB}$. The published values of the ${ }^{1} \mathrm{O}_{2}$ lifetime and the derived calculated mean molecular trajectories led to the conclusion that in the heterogeneous system studied by us and containing photosensitizer, ZSM-5-MB conditions conducive to inactivation of microorganisms prevail (in spite of longer diffusion path of ${ }^{1} \mathrm{O}_{2}$ through the zeolite channels).

Ultrastructural changes in the cells of E. coli, S. aureus, and $C$. albicans were analyzed by TEM. This microscopy represents a suitable tool for evaluation of morphology and microstructure of microorganism cells ( $\mathrm{Wu}$ et al. 2010). Fig. 8 shows a representative TEM picture of E. coli (a), $S$. aureus (c), and C. albicans (e) cells prior to 
photoinactivaton. In these undamaged samples cells of bacteria, yeast possess a well-defined shape, regular cell wall outline, and stable inner compartments, corresponding to full inner zone of proteins and DNA molecules. After inactivation by red light in the presence of photocatalyst ZSM-5-MB, cell morphologies were unambiguously changed. It follows form Fig. 7b, d, and f that the photodynamic effect caused ultrastructural changes in them (sample of microorganisms for TEM analysis was taken at time of reaching $\mathrm{IC}_{50}$ ). On TEM pictures, the changes manifested themselves mainly by the destruction of cell wall and cell membrane, even to depletion of inner cell material (not seen in the picture). After being photodynamically hit, some cells almost completely "lost" their contour. At such extent of damage to cell wall, the cytoplasm and the inner cell compartments can freely flow out and thus inactivating the cells.

In order to elucidate and quantify the effectiveness of inactivation of pathogenic microorganisms by photogenerated ${ }^{1} \mathrm{O}_{2}$ in more detail, we compared the amount of MB in the medium required for $50 \%$ inhibition effectiveness $\left(\mathrm{IC}_{50}\right)$ in experiments when light cultivation of media with dissolved MB was used as well as for experiments when MB was immobilized in the zeolite pores (Table 1).

The comparison revealed that concentration required for $\mathrm{IC}_{50}$ was in case of $C$. albicans and E. coli one order of magnitude lower for a zeolite-immobilized dye than it was for a freely dissolved dye. In S. aureus, this concentration was even lower by four orders of magnitude. Such enhancement of microorganism toxicity in immobilized MB over dissolved MB can be accounted for by accelerated ${ }^{1} \mathrm{O}_{2}$ generation at MB-treated zeolite surface, which being in physical proximity of to the surface attached microorganisms immediately diffuses into the membrane structure. Since it may likewise be assumed that in such a system the photoinactivation effect is based on mechanism type 2 , it is less likely that the nonirradiated environment would be damaged, even though the dissolved MB could have diffused into it. Study of Kohno et al. (2008) reported that when the dye is incorporated into the pore of the zeolites, the stability of complex is enhanced, and a large stabilization effect is obtained by a tight adsorption with a narrow pore, as long as the dye is incorporated into the pore, and therefore, we could assume of more efficiently control of ${ }^{1} \mathrm{O}_{2}$ generation. Enhanced antimicrobial effect of a photoactive MB, in the colloids of clay mineral, was observed in the work of Bujdák et al. (2009). Surprisingly, while MB adsorbed on clay minerals lost the ability to produce ${ }^{1} \mathrm{O}_{2}$ due to molecular aggregation, the photoantimicrobial activity was significantly enhanced. In the study of Rychtáriková et al. (2012), mesoporous organosilica-porphyrin composites showed high biocidal efficiency for the inactivation of $E$. coli BL21(DE3) (pET16bDsRed) strain. The disinfection efficiency against $E$. coli in water of new silica-based materials containing aromatic photosensitizers was studied by Benabbou et al. (2011). Bonnett et al. (2006) tested several photosensitizers in E. coli inactivation and demonstrated that the chitosan-phthalocyanine association was the most effective to inactivate microorganisms. As can be seen, there is a strong demand to identify new strategies for disinfection as well as treatment of plant, animal, or human pathogens.

\section{Conclusion}

The system with the MB and ZSM-5 zeolite was more efficient in the reduction in surviving cells than those containing $\mathrm{MB}$ alone. It is also possible charge that the addition of zeolite materials significantly enhanced the photoantimicrobial efficiency of MB. The greatest difference was observed in the combination of $\mathrm{MB}$ and zeolite materials for $S$. aureus. The enhanced photoantimicrobial activity of ZSM-5-MB complex was confirmed also for E. coli and C. albicans. Thus, MB fixed in the zeolite microstructure is photochemically active and takes part in the generation of singlet oxygen as shown above. Moreover, by incorporation of MB into zeolite channels, cavities may decelerate her gradual release into the medium, and therefore, it can be more probably assumed a more effective control of the singlet oxygen generation.

Acknowledgments The work has been supported by the Ministry of Education in the Slovakia (Grant No. 1/0879/11). The authors thank Jaroslav Kováč and Pavol Hronec (Department of Microelectronics, Institute of Electronics and Photonics, Faculty of Electrical Engineering and Information Technology, Slovak University of Technology, Ilkovičova 3, 81219 Bratislava, Slovakia) for the emission spectrum and flux density measurement of LEDs system.

\section{References}

Arvand M, Sohrabnezhad S, Mousavi MF, Shamsipur M, Zanjanchi MA (2003) Electrochemical study of methylene blue incorporated into mordenite type zeolite and its application for amperometric determination of ascorbic acid in real samples. Anal Chim Acta 491:193-201. doi:10.1016/S0003-2670(03) 00790-6

Benabbou AK, Guillard C, Pigeot-Rémy S, Cantau C, Pigot T, Lejeune P, Derriche Z, Lacombe S (2011) Water disinfection using photosensitizers supported on silica. J Photochem Photobiol, A 219:101-108. doi:10.1016/j.jphotochem.2011.01.023

Bonnett R, Krysteva MA, Lalov IG, Artarsky SV (2006) Water disinfection using photosensitizers immobilized on chitosan. Water Res 40:1269-1275. doi:10.1016/j.watres.2006.01.014

Bujdák J, Jurečeková J, Bujdáková H, Lang K, Šeršeň F (2009) Clay mineral particles as efficient carriers of methylene blue used for antimicrobial treatment. Environ Sci Technol 43:6202-6207. doi:10.1021/es900967g 
Calzaferri G, Gfeller N (1992) Thionine in the cage of zeolite L. J Phys Chem 96(8):3428-3435. doi:10.1021/j100187a047

Calzavara-Pinton PG, Venturini M, Sala R (2005) A comprehensive overview of photodynamic therapy in the treatment of superficial fungal infections of the skin. J Photochem Photobiol, B 78:1-6. doi:10.1016/j.jphotobiol.2004.06.006

Caro J, Noack M, Richter-Mendau J, Marlow F, Petersohn D, Griepentrog M, Kornatowski J (1993) Selective sorption uptake kinetics of $n$-hexane on ZSM 5-a new method for measuring anisotropic diffusivities. J Phys Chem 97:13685-13690

Chrétien MN (2007) Supramolecular photochemistry in zeolites: from catalysts to sunscreens. Pure Appl Chem 79:1-20. doi:10.1351/ pac200779010001

Č́́k G, Bujdáková H, Šeršeň F (2001) Study of fungicidal and antibacterial effect of the $\mathrm{Cu}$ (II)-complexes of thiophene oligomers synthesized in ZSM-5 zeolite channels. Chemosphere 44:313-319

Čík G, Priesolová $S$, Bujdáková $H$, Šeršeň $F$, Potheőová $T$, Krištín $J$ (2006) Inactivation of bacteria $\mathrm{G}^{+}-\mathrm{S}$. aureus and $\mathrm{G}^{-}$-E. coli by phototoxic polythiophene incorporated in ZSM-5 zeolite. Chemosphere 63:1419-1426. doi:10.1016/j.chemosphere.2005.10.017

Roncucci G, Dei D, De Filippis MP, Fantetti L, Masini I, Cosimelli, B, Jori G (2011) Zinc-phthalocyanines and corresponding conjugates, their preparation and use in photodynamic therapy and as diagnostic agents. European patent EP0906758

Dahl TA, Midden WR, Hartman PE (1989) Comparison of killing of gram-negative and gram-positive bacteria by pure singlet oxygen. J Bacteriol 171:2188-2194

Dougherty TJ, Gomer CJ, Henderson BW, Jori G, Kessel D, Korbelik M, Moan J, Peng Q (1998) Photodynamic therapy. J Natl Cancer Inst 90:889-905. doi:10.1093/jnci/90.12.889

Ergaieg K, Seux R (2009) A comparative study of the photoinactivation of bacteria by meso-substituted cationic porphyrin, rose Bengal and methylene blue. Desalination 246:353-362. doi:10. 1016/j.desal.2008.03.060

Gabrielli D, Belisle E, Severino D, Kowaltowski AJ, Baptista MS (2004) Binding, aggregation and photochemical properties of methylene blue in mitochondrial suspensions. Photochem Photobiol 79:227-232. doi:10.1111/j.1751-1097.2004.tb00389.x

Gelfuso GM, Gratieri T, Souza JG, Thomazine JA, Lopez RFV (2011) The influence of positive or negative charges in the passive and iontophoretic skin penetration of porphyrins used in photodynamic therapy. Eur J Pharm Biopharm 77:249-256. doi:10.1016/j.ejpb.2010.11.018

Gois MM, Kurachi C, Santana EJ, Mima EG, Spolidório DM, Pelino JE, Salvador Bagnato V (2010) Susceptibility of Staphylococcus aureus to porphyrin-mediated photodynamic antimicrobial chemotherapy: an in vitro study. Lasers Med Sci 25:391-395. doi:10.1007/s10103-009-0705-0

Hamblin MR, Hasan T (2004) Photodynamic therapy: a new antimicrobial approach to infectious disease? Photochem Photobiol Sci 3:436-450. doi:10.1039/B311900A

Harris F, Chatfield LK, Phoenix DA (2005) Phenothiazinium based photosensitisers-Photodynamic agents with a multiplicity of cellular targets and clinical applications. Curr Drug Targets 6(5):615-627

Houghtby GA, Maturin LJ, Koenig EK (1992) Microbiological counts methods. In: Marshall RT (ed) Standard methods for the examination of dairy products, 16th edn. American Public Health Association, Washington, pp 213-246

Jin X, Jiang M-Q, Shan X-Q, Pei Z-G, Chen Z (2008) Adsorption of methylene blue and orange II onto unmodified and surfactantmodified zeolite. J Colloid Interface Sci 328:243-247. doi:10. 1016/j.jcis.2008.08.066

Jockusch S, Sivaguru J, Turro NJ, Ramamurthy V (2005) Direct measurement of the singlet oxygen lifetime in zeolites by near-
IR phosphorescence. Photochem Photobiol Sci 4:403-405. doi:10.1039/B501701G

Jori G, Fabris C, Soncin M, Ferro S, Coppellotti O, Dei D, Frantetti L, Chiti G, Roncucci G (2006) Photodynamic therapy in the treatment of microbial infections: basic principles and perspective applications. Lasers Surg Med 38:468-481. doi:10.1002/ $1 \mathrm{sm} .20361$

Kohno Y, Shibata Y, Oyaizu N, Yoda K, Shibata M, Matsushima R (2008) Stabilization of flavylium dye by incorporation into the pore of protonated zeolites. Micropor Mesopor Mat 114:373-379. doi:10.1016/j.micromeso.2008.01.023

Krouit M, Granet R, Branland P, Verneuil B, Krausz P (2006) New photoantimicrobial films composed of porphyrinated lipophilic cellulose esters. Bioorg Med Chem Lett 16:1651-1655. doi:10. 1016/j.bmcl.2005.12.008

Lacombe S, Soumillion JP, El Kadib A, Pigot T, Blanc S, Brown R, Oliveros E, Cantau C, Saint-Cricq P (2009) Solvent-free production of singlet oxygen at the gas-solid interface: visible light activated organic-inorganic hybrid microreactors including new cyanoaromatic photosensitizers. Langmuir 25:1116811179. doi:10.1021/la901504q

Lang K, Mosinger J, Wagnerová DM (2005) Progress in photochemistry of singlet oxygen. Chem Listy 99:211-221

Ledford HK, Niyogi KK (2005) Singlet oxygen and photo-oxidative stress management in plants and algae. Plant, Cell Environ 28:1037-1045. doi:10.1111/j.1365-3040.2005.01374.x

Lee D, Foux M, Leonard EF (1997) The effects of methylene blue and oxygen concentration on the photoinactivation of $\mathrm{Q} \beta$ bacteriophage. Photochem Photobiol 65:161-165. doi:10.1111/j.17511097.1997.tb01893.x

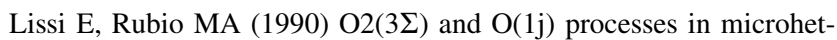
erogeneous systems. Pure Appl Chem 62:1503-1510

Mellish KJ, Cox RD, Vernon DI, Griffiths J, Brown SB (2002) In vitro photodynamic activity of a series of methylene blue analogues. Photochem Photobiol 75(4):392-397

Merchat M, Bertolini G, Giacomini P, Villaneuva A, Jori G (1996) Meso-substituted cationic porhyrins as efficient photosensitizers of gram-positive and gram-negative bacteria. J Photochem Photobiol, B 32:153-157. doi:10.1016/1011-1344(95)07147-4

Meteš A, Kovačević D, Vujević D, Papić S (2004) The role of zeolites in wastewater treatment of printing inks. Water Res 38:3373-3381. doi:10.1016/j.watres.2004.04.012

Minnock A, Vernon DI, Schofield J, Griffiths J, Parish JH, Brown ST (1996) Photoinactivation of bacteria. Use of a cationic watersoluble zinc phthalocyanine to photoinactivate both gramnegative and gram-positive bacteria. J Photochem Photobiol, B 32:159-164. doi:10.1016/1011-1344(95)07148-2

Mosinger J, Jirsák O, Kubát P, Lang K, Mosinger B (2007) Bacteridal nanofabrics based on photoproduction of singlet oxygen. J Mater Chem 17:164-166. doi:10.1039/B614617A

Paardekopper M, Van Gompel AE, Van Steveninck J, Van de Broek J (1995) The effect of photodynamic treatment of yeast with the sensitiser chloroaluminium phthalocyanine on various cellular parameters. J Photochem Photobiol, B 62:561-567. doi:10.1111/ j.1751-1097.1995.tb02385.x

Pace A, Clennan EL (2002) A new experimental protocol for intrazeolite photooxidations. The first product-based estimate of an upper limit for the intrazeolite singlet oxygen lifetime. J Am Chem Soc 124:11236-11237. doi:10.1021/ja027053w

Pavlíková S, Šeršeň F, Jesenák K, Čík G (2010) Degradation of 4-chlorophenol by modified natural zeolites. Fresenius Environ Bull 29:1486-1490

Peloi LS, Soares RRS, Biondo CEG, Souza VR, Hioka N, Kimura E (2008) Photodynamic effect of light-emitting diode light on cell growth inhibition induced by methylene blue. J Biosci 33:231-237. doi:10.1007/s12038-008-0040-9 
Phoenix DA, Harris F (2003) Phenothiazinium-based photosensitizers: antibacterials of the future? Trends Mol Med 9:283-285. doi:10.1016/S1471-4914(03)00115-1

Redmond RW, Kochevar IE (2006) Spatially resolved cellular responses to singlet oxygen. Photochem Photobiol 82:1178-1186. doi:10.1562/2006-04-14-IR-874

Roncucci G, Dei D, De Filippis MP, Fantetti L, Masini I, Cosimelli B, Jori G (2011) Zinc-phthalocyanines and corresponding conjugates, their preparation and use in photodynamic therapy and as diagnostic agents. European Patent EP0906758

Roncucci G, Fantetti L, De Filippis MP, Dei D, Jori G (2004) Substituted metal phthalocyanines, their preparation and use thereof. European patent EP1164135

Rychtáriková R, Šabata S, Hetflejš J, Kuncová G (2012) Photodynamic efficiency of porphyrins encapsulated in polysilsesquioxanes. Chem Pap 66(4):269-277. doi:10.2478/s11696-012-0153-3

Saif Ur Rehman M, Han JI (2013) Biosorption of methylene blue from aqueous solutions by Typha angustata phytomass. Int $\mathbf{J}$ Environ Sci Tech 10(4):840-865. doi:10.1007/s13762-0120128-5

Schirmer RH, Coulibaly B, Stich A, Scheiwein M, Merkle H, Eubel J, Becker K, Becher H, Müller O, Zich T, Schiek W, Kouyaté B (2003) Methylene blue as an antimalarian agent. Redox Rep 8:272-275. doi:10.1179/135100003225002899

Schmidt I, Madsen C, Jacobsen CJH (2000) Confined space synthesis. A novel route to nanosized zeolites. Inorg Chem 39:2279-2283. doi:10.1021/ic991280q

Šeršeň F, Pavlíková S, Jesenák K, Szocs V, Čík G (2011) Effect of methylene blue and chlorophyllin embedded in natural zeolite on algae growth in medium polluted by 4-chlorophenol. Fresenius Environ Bull 19:2271-2276
Shirazi L, Jamshidi E, Ghasemi MR (2008) The effect of Si/Al ratio of ZSM-5 zeolite on its morphology, acidity and crystal size. Cryst Res Technol 43:1300-1306. doi:10.1002/crat.200800149

Tardivo JP, Del Giglio A, de Oliveira CS, Gabrielli DS, Junqueira HC, Tada DB, Severino D, de Fátima Turchiello R, Baptista MS (2005) Methylene blue in photodynamic therapy: from basic mechanisms to clinical applications. Photodiagn Photodyn 2:175-191. doi:10.1016/S1572-1000(05)00097-9

Wainwright M (1996) Non-porphyrin photosensitizers in biomedicine. Chem Soc Rev 25:351-359

Wainwright M, Crossley KB (2002) Methylene blue-a therapeutic dye for all seasons? J Chemother 14:431-433

Wainwright M, Phoenix DA, Marland J, Wareing DRA, Bolton FJ (1996) A study of photobactericidal activity in the phenothiazinium series. FEMS Immunol Med Mic 19:75-80. doi:10.1111/j. 1574-695X.1997.tb01074.x

Weishaupt KR, Gomer CJ, Dougherty TJ (1976) Identification of singlet oxygen as the cytotoxic agent in photoinactivation of a murine tumor. Cancer Res 36:2326-2329

Wilson M, Burns T, Pratten J, Pearson GJ (1995) Bacteria in supragingival plaque samples can be killed by low-power laser light in the presence of a photosensitizer. J Appl Bacteriol 78:569-574. doi:10.1111/j.1365-2672.1995.tb03101.x

Wu P, Imlay JA, Ku Shang J (2010) Mechanism of Escherichia coli inactivation on palladium-modified nitrogen-doped titanium dioxide. Biomaterials 31:7526-7533. doi:10.1016/j.biomaterials. 2010.06.032

Zeina B, Greenman J, Purcell WM, Das B (2001) Killing of cutaneous microbial species by photodynamic therapy. $\mathrm{Br} \mathrm{J}$ Dermatol 144:274-278. doi:10.1046/j.1365-2133.2001.04013.x 